\title{
Techniques for Medical Dictionary Translation
}

\author{
Ruben Dharmawan \\ Universitas Sebelas Maret \\ Surakarta, Indonesia \\ rubendharmawan@yahoo.com \\ Sri Samiati Tarjana \\ Universitas Sebelas Maret \\ Surakarta, Indonesia
}

\author{
M.R. Nababan \\ Universitas Sebelas Maret \\ Surakarta, Indonesia \\ amantaradja@gmail.com \\ Djatmika \\ Universitas Sebelas Maret \\ Surakarta, Indonesia \\ djatmika@staff.uns.ac.id
}

\begin{abstract}
The paper is an embedded-case study approaching medical dictionary translation techniques that requires specific skills from the translator. The purposively selected sources of data consist of tropical medicine related entries of the 31st Dorland's Illustrated Medical Dictionary human and web translations, key informants and respondents. Findings of the study show that seventeen translation techniques such as naturalized and pure borrowings and established equivalent, literal, transposition, explicitation, implicitation, particularization, discursive creation, generalization, reduction, addition, ommision, description, modulation and compensation were detected in human translation. Web translation used the similar techniques except compensation but unintentionally created unintelligible translation. Combined translation techniques such as couplets, triplets and quadruplets were found in both types of translations. It is concluded that techniques for medical dictionary human and web translations as specialised, scientific and non literary translations could apply the existing procedures.
\end{abstract}

Keywords-translation techniques, medical dictionary, human and web translation.

\section{INTRODUCTION}

One of several tools for analysing translation quality assessment is translation technique. Translation of medical texts, including medical dictionary, should be accurate, acceptable and readable as medicine closely relates to physical and mental health (Nababan et al., 2012:44\&45). There are at least two types of medical dictionary translation: human and web translations. Human translation is often available in hardcopy such as printed books and web translation is a machine translation transmitted by internet. Human translator is able to feel and interpret condition and situation and has a special capability but limited by time and place and expensive (Foden-Vencil, 2014:1). Flores et al. (2003:1) investigated the frequency, categories, and potential clinical consequences of errors in medical interpretation. The most common error type was omission (52\%), followed by false fluency $(16 \%)$, substitution (13\%), editorialization (10\%), and addition $(8 \%)$. Sixty-three percent of all errors had potential clinical consequences.

On the other hand, web translation cannot feel nor interpret and has limited capability but almost unlimited to place and time that makes useful in critical situation, e.g. in hospital. Once, Patil and Davies (2014:1) treated a very sick child and there were no human translators available. Reluctantly they resorted to Google Translate, a web based translation tool to find some translation to explain the condition of the patient. Fortunately a human translator later reassured them that they had conveyed information accurately. However, they found Google Translate has only $57.7 \%$ accuracy and limited usefulness for medical phrases used in communications between patients and doctor. They advised that caution is needed when life saving or legal communications are necessary and it can be a useful adjunct to human translation services when these are not available. Taylor (2011:123) added that "For the medical writer, being "right" is paramount. More than probably any other discipline, medical science is unforgiving about errors".

Medical translation technique is classified into nonliterary, scientific dan spesialized translation it utilizes translation techniques of linguistic experts. However, Molina dan Albir (2002:506\&507) found that there is confusion about terminology, concepts and classification of translation techniques. A technique is the result of a choice made by a translator and can only be judged meaningfully when it is evaluated within a particular context, in this case is the $31^{\text {st }}$ Dorland's Illustrated Medical Dictionary human and web translations. Translation techniques are not good or bad in themselves, they are used functionally and dynamically in terms of: 1) genre of the text (medical texts or dictionary, etc.); 2) type of translation (technical, scientific, literary, etc.); 3) mode of translation (human or web translation, etc.); 4) purpose of the translation and the characteristics of the translation audience; 5) method chosen (communicative, etc.). Further, Molina dan Albir (2002:509) define translation techniques as procedures to analyse and classify how translation equivalence works with five basic characteristics: 1) affect the result of the translation, 2) are classified by comparison with the original, 3) affect micro-units of text, 4) are by nature discursive and contextual and 5) are functional.

Đorđević (2017:40) and Molina and Albir (2002:499) stated that Vinay and Darbelnet (1958) offered the first, basic and valid translation techniques (procedures) with a clear 
methodological purpose. Vinay and Darbelnet (1995: 30-40, as translated by Sager and Hamel) defined seven basic procedures clasified as direct (or literal) or oblique translation. The direct translation are: borrowing, calque and literal translation. The oblique translation procedures are: transposition, modulation, equivalence and adaptation. These seven basic procedures are complemented by opposing pairs, except compensation and inversion: concentration vs dissolution, amplification vs economy, reinforcement vs condensation, explicitation vs implicitation, and generalization vs particularization. Newer techniques proposed after that, in particular by Nida (2001): additions, subtractions and alterations; by Newmark (1988:45-48): recognized translation, functional equivalent, neutralization and translation label. Newmark (1988:81) wrote that "while translation methods relate to whole texts, translation procedures are used for sentences and the smaller units of language" and indicated that word-for-word, literal, faithful and semantic translations are closer to source texts while adaptation, free, idiomatic and communicative translations are closer to target texts; and also mentioned combination translations as couplets, triplets and quadruplets. Molina and Albir (2002:510-511) added description, discursive creation, linguistic compression, reduction, substitution and variation; and Morón and Calvo (2018): transcreation. These newer classifications have been a result of particular needs and issues (Molina and Albir, 2002; Munday, 2012).

In the sense of translation techniques above, Hariyanto (2015:118) based translation strategies on application of equivalence: below sentence levels, sentence level and textual level. The translation strategies used in web translation: literal translation, loan and calque that can be classified as borrowing (pure borrowing and naturalized borrowing), paraphrasing, transposition, free translation, adaptation, modulation (or structure change or converse), cultural filtering, interpersonal change, information change (in the form of addition or omission), scheme change, trope change and combination and also antonymy, hyponymy and synonymy. Hariyanto (2015:139) stated that basically, translators try to translate sentences using literal translation. Sigalingging (2017:98) mentioned the implementation of 14 translation techniques, namely literal translation, transposition, borrowing, established equivalence, modulation, reduction, adaptation, amplification, particularization, generalization, linguistic compression, discursive creation, linguistic amplification, and calque. Literal translation and transposition are the most dominant translation techniques used by translators.

\section{METHOD}

The study utilized a qualitative method and an embedded-case study approaching medical dictionary translation techniques. The purposively selected sources of data consist of tropical medicine related entries and its explanation of the $31^{\text {st }}$ Dorland's Illustrated Medical Dictionary human and web translations, key informants and respondents. The units of translation consisted of words, medical terms, phrases and sentences were processed in a focus group discussion in July, 2017.

\section{RESULT AND DISCUSSION}

Findings of the study showed that seventeen translation techniques such as naturalized, pure and established equivalent, literal, transposition, explicitation, implicitation, particularization, discursive creation, generalization, reduction, addition, ommision, description and compensation were detected in human translation. Web translation used the similar techniques except compensation and description but sometimes created unintelligible translation. Combined translation techniques were found in both types of translation. Two examples are seen below.

Table 1. Techniques for human and web translations of caseation entry (no 029).

\begin{tabular}{|c|c|c|}
\hline $\begin{array}{c}\text { caseation } \\
\text { original }\end{array}$ & $\begin{array}{c}\text { caseation } \\
\text { human translation }\end{array}$ & $\begin{array}{c}\text { caseation } \\
\text { web translation }\end{array}$ \\
\hline caseation [L. & caseation [L. caseus keju] & caseation [L. keju kotakus] \\
\hline $\begin{array}{l}\text { caseus } \\
\text { cheese] the }\end{array}$ & $\overline{p m} \quad \overline{p m} \overline{p m} \overline{p l}$ & $p m \quad \overline{p l} \overline{p l} \quad \overline{k d(?)}$ \\
\hline precipitation & presipitasi casein. & pengendapan kasein. \\
\hline of casein & pm & $p l \quad p a$ \\
\hline
\end{tabular}

Human translation consists of 6 (six) words: 4 (four) words are translated using peminjaman murni $(\mathrm{pm})$ that is pure borrowing, 1 (one) padanan lazim $(\mathrm{pm})$ that is established equivalent and 1 (one) peminjaman alamiah (pm) or naturalized borrowing. In other words, all of the words are literal translations and combined translations.

Web translation consists of 6 (six) words: 1 (one) word is translated using $p m, 3$ (three) words $p l$ and 1 (one) word pa. One special phrase, keju kotakus, which was translated from caseus cheese is worth discussed as its meaning difficult to understand. Searching through Google revealed no equivalent word, and the word kotakus was not found in KBBI Daring 2018, caseus was also not found in Oxford Advanced Learner's Dictionary. Some translation techniques were consulted i.e. literal translation, loan word or calque (borrowing), equivalence, established equivalent, adaptation, alterations, description and discursive creation $(k d)$.

Literal translation is word for word translation. Loan word or calque is a foreign word or phrase translated and incorporated into another language. Borrowing is defined as a word taken directly from another language. Equivalence accounts for the same situation using a completely different phrase. Established equivalent means to use a term or 
expression recognized by dictionaries or language in use as an equivalent in the target language. Adaptation is a shift in cultural environment, i.e., to express the message using a different situation. Alterations are changes have to be made because of incompatibilities between the two languages; Description means to replace a term or expression with a description of its form or/and function. Discursive creation is to establish a temporary equivalence that is totally unpredictable out of context.

In the discussion, the phrase was said using creative discursion revealing keju kotakus as a temporary equivalence that is totally unpredictable out of context and the phrase was not understable. A possible explanation that Google Translate has produced such unintelligible translation - a modification term of unintelligible component in fluency criteria of Multidimensional Quality Metrics (MQM) for web translation (Mariana, 2015:137) - is mechanism failure of the machine translation for medical dictionary terms.

Table 2. Techniques in human and web translations of no 007 chloroquine entry.

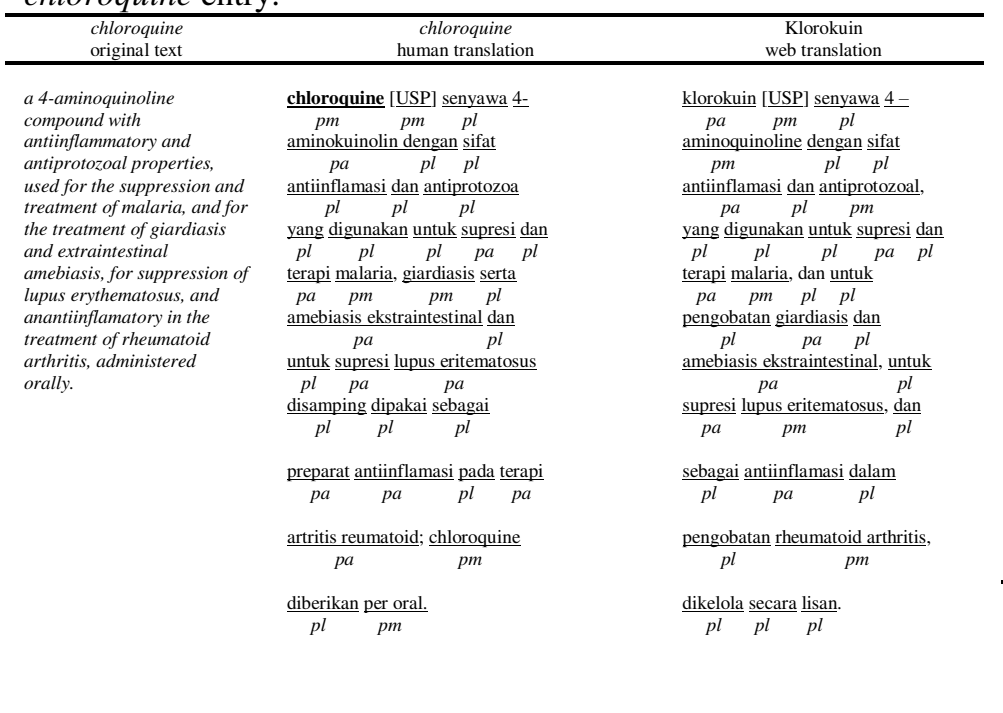

There is ommision in human translation worth notified, that is for the treatment of (giardiasis and extraintestinal amebiasis). This ommision is a maltranslation, since chloroquine cannot suppress or stop the clinical course of giardiasis (Kusmartisnawati in Hadidjaja and Margono, 2011:61-62). Then, if it is really administered it is a mistherapy that will endanger the health of a patient. Pym (2010:3) wrote "Omission is a common enough strategy, especially in low-risk situations. However, it might give a high-risk rendition, ..." Vázquez Ayora (1977, in Molina and Albir, 2002:504) defined omission as to omit redundancy and repetition that is characteristic of the source language. In fact, in the source sentence, redundancy and repetition were not so frequent that the words should be omitted. The translators might have been in a rush. This happening gave web translation positive value over human translation. Patil and Davies (2014:1) have taken the advantages when human translators were not at site. Kelly (2010:1) noted that the absence of a professional interpreter in a hospital and web translation was not consulted, misinterpretation or mis-literal translation happened: "intoxicado" was mistranslated into "intoxicated" of an admitted patient. Intoxicated means an intentional overdose and led to a misdiagnosis, the wrong course of treatment, and eventually, to his quadriplegia. It also resulted in a malpractice settlement of $\$ 71 \mathrm{~m}$. Fakler et al. (2007:1) pointed out mistranslation made by human translator of package label of orthopaedic implants. The translation technique was reduction of "non-modular cemented" to "noncemented" and literal translation from "non-modular cemented" to "without cement". The technique of reduction means to suppress a source text information item in the target text.

In web translation, Google translate applied literal translation to administered orally and resulted as dikelola secara lisan. This phenomenon proves that web translation cannot interpret well enough.

Units of translation in the $31^{\text {st }}$ Dorland's Illustrated Medical Dictionary are tabulated as follows.

Table 3. Distribution of units of translation in the $31^{\text {st }}$ Dorland's Illustrated Medical Dictionary.

\begin{tabular}{clcc}
\hline Units of translation & $\begin{array}{c}\text { Human } \\
\text { Translation }\end{array}$ & $\begin{array}{c}\text { Web } \\
\text { Translation }\end{array}$ \\
\hline 1. & Words & 1,836 & 2,060 \\
2. & Terms & 362 & 365 \\
3. & Phrases & 460 & 467 \\
4. & Sentences & 148 & 142 \\
\hline
\end{tabular}

Total units of translation in human translation are 2806 and in web translation are 3034 consist of words, terms, phrases and sentences.

Translation techniques used in human and web translations are tabulated below.

Table 3. Frequency of translation techniques used in the $31^{\text {st }}$ Dorland's Illustrated Medical Dictionary human and web translations.

\begin{tabular}{cll}
\hline Translation Techniques & $\begin{array}{l}\text { Human } \\
\text { Translation }\end{array}$ & $\begin{array}{l}\text { Web } \\
\text { Translation }\end{array}$ \\
\hline 01. Established & 916 & 924 \\
equivalent & 234 & 181 \\
02. Pure borrowing & 178 & 126 \\
03. Combination & 61 & 59 \\
\hline
\end{tabular}




$\begin{array}{lll}\text { 04. Naturalized } & 35 & 8 \\ \text { borrowing } & 21 & 3 \\ \text { 05. Explicitation } & 13 & 34 \\ \text { 06. Modulasi } & 6 & 3 \\ \text { 07. Discursive creation } & 6 & 7 \\ \text { 08. Implicitation } & 5 & 4 \\ \text { 09. Reduction } & 4 & 4 \\ \text { 10. Transposition } & 3 & 3 \\ \text { 11. Particularization } & 2 & 1 \\ \text { 12. Ommision } & 2 & 78 \\ \text { 13. Addition } & 2 & 4 \\ \text { 14. Literal } & 1 & 0 \\ \text { 15. Generalization } & 1 & 0 \\ \text { 16. Description } & & \\ \text { 17. Compensation } & & \end{array}$

The 3 (three) most used translation techniques in human translation are established equivalent, pure borrowing and combination as well as in web translation. The data support that the existing translation techniques are applicable for non-literary, scientific and specialised human and web translations including medical dictionary. However, the quality of translations should be further assessed immediately.

It is observed that the frequency of literal translation in web translation (78) is much higher than in human translation (2). This condition matches the observation of Hariyanto (2015:150) and Sigalingging (2017:107) that literal translation frequently used in web translation. One of the reasons might be the requirement of using literal translation: "Literal translation occurs when there is an exact structural, lexical, even morphological equivalence between two languages. According to the authors, this is only possible when the two languages are very close to each other" (Molina and Albir, 2002:499). This requirement is strictly applied by human translator but not by machine translator. Machine translation probably take the word for word as literal translation.

\section{CONCLUSION}

1. Ommision could lead to maltranslation that deteriorate patient health. This ommision happened in human translation.

2. Web translation, in this case Google translate, may operate a strange translation technique which result in unintelligible translations, i.e. kotakus from caseous and dikelola secara lisan from (a drug that should be) administered orally.

3. Medical dictionary human and web translations utilize the same three most common techniques i.e. established equivalent, pure borrowing and combination.
4. Translation techniques are not good or bad in themselves, however their function and dynamic characters should be used cautiously and correctly in human translation as to avoid the futures that do not need translators (van der Meer, 2016:1).

\section{References}

Đorđević, Jasmina P. 2017. Translation Techniques Revisited: The Applicability of Existing Solutions in Non-literary Translation. Facta Universitatis. Series: Linguistics and Literature Vol. 15, No 1, pp. 35-47.

Foden-Vencil, Kristian. 2014. In The Hospital, A Bad Translation Can Destroy A Life. Shots Health News From NPR. Pp. 2.

Hariyanto, Sugeng. 2015. Website Translation (with special reference to English - Indonesian language pair). Revised and Enriched second edition. Penerbit Inspira. Malang. Pp. 143- 165.

Kelly, Nataly. 2010. The value of a single word. The BMJ. BMJ Publishing Group Limited. Pp. 1-3.

Kementerian Pendidikan dan Kebudayaan. 2016. Pedoman Umum Ejaan Bahasa Indonesia (PUEBI). Panitia Pengembang Pedoman Bahasa Indonesia. Jakarta: Badan Pengembangan dan Pembinaan Bahasa. 78 hlm. ISBN 978-979-069-262-6.

Kusmartisnawati. 2011. Giardiasis. Dalam Hadidjaja, P dan Sri S. Margono (Editor): Dasar Parasitologi

Klinik. Badan Penerbit Fakultas Kedokteran Universitas Indonesia. Edisi Pertama. Halaman: 61-62.

Mariana, Valerie, Troy Cox and Alan Melby. 2015. The Multidimensional Quality Metrics (MQM) Framework: a new framework for translation quality assessment. The Journal of Specialised Translation. Issue 23: 137161.

Molina, Lucía and Amparo Hurtado Albir. 2002. Translation techniques Revisited: A Dynamic and Functionalist Approach. Meta, XLVII, 4, 2002. Pp. 498-512.

Morón, Marián and Elisa Calvo. 2018. Introducing transcreation skills in translator training contexts: A situated project-based approach. The Journal of Specialised Translation Issue 29, 126-148.

Munday, Jeremy. 2012. Evaluation in Translation. Critical Points of Translator Decision- Making.

Routledge. Taylor and Francis Group. London and New York. 203 Halaman.

Nababan, M.R., Nuraeni, A., dan Sumardiono. 2012. Pengembangan Model Penilaian Kualitas Terjemahan. Kajian Linguistik dan Sastra, Vol. 24, No.1. 39-57.

Newmark, Peter. 1988. A Textbook of Translation. Prentice Hall International Ltd. xii +296 halaman. 
Nida, Eugene Albert. 2001. Contexts in Translating. Benjamins Translations Library, ISSN 0929. 7316.

Patil, Sumant \& Patrick Davies. 2014. Use of Google Translate in Medical Communication: Evaluation of Accuracy. BMJ. 349:g7392.

Pym, Anthony. 2010. Text and Risk in Translation. In Sidiropoulou, Maria, Papaconstantinou, Anastasia (Eds). Athens: The National and Kapodostrian University of Athens: Choice and Difference in Translation: The Specifics of Transfer. 27-42.usuaris.tinet.cat/apym/online/translation/risk_analysis.pdf.

Pym, Anthony. 2015. Translating as risk management. Intercultural Studies Group. Universitat Rovira i Virgili. Tarragona. Spain. Journal of Pragmatics 85 (2015) $67-80$.
Sigalingging, Bob M. 2017. Realization of Decision Making in the Translation Process of

the Web Content of www.ayodya.com. Journal Of Language And Literature Vol 5, No. 2.

Taylor, Robert B. 2011. Medical Writing: A Guide for Clinicians, Educators and Researchers. Springer Science+Business Media LLC. xiv +372 pages.

Van der Meer, Jaap. 2016. The Future Does Not Need Translators. https://www.taus.net/.

Vázquez-Ayora, G. 1977. Introducción a la traductología, Washington: Georgetown University Press.

Vinay, Jean Paul and Jean Darbelnet. 1995. [Stylistique comparée du français et de l'anglais.

English]. Comparative stylistics of French and English : a methodology for translation. Translated and edited by Juan C. Sager, M.-J. Hamel. Benjamins Translation Library, ISSN 0929-7316 ; v. 11. 